\title{
Political Instability, Corruption, and Economic Growth: Evidence from a Panel of OECD Countries
}

\author{
Emin Ahmet Kaplan ${ }^{a}$
}

\author{
Alpaslan Akçoraoğlu ${ }^{\mathrm{b}}$
}

\begin{abstract}
The major aim of this paper is to examine the empirical relations between economic growth and a broad group of political instability factors including corruption, government instability, internal and external conflicts, religious and ethnic tensions, democratic accountability and bureaucracy quality. Moreover, one of the main objectives of our paper is to explore the effects of serious problems such as political instability and corruption on economic growth for a panel of OECD countries by using the system-GMM (Generalized Method of Moments) estimator during the period 1984-2012. Our findings confirm most of the literature that political instability is negatively associated with economic growth. We found strong evidence in favor of the hypothesis that corruption negatively affects economic growth. Our paper presents strong evidence in favor of the view that government stability and internal and external conflicts are obstacles for rapid economic growth. However, the results of system-GMM estimation indicate that democratic accountability, ethnic and religious tensions and bureaucracy quality have no statistically significant impact on economic growth of $O E C D$ countries.
\end{abstract}

Keywords: Political Instability, Corruption, Economic Growth, Political Conflict

JEL Classification: D72, D73, 043, P48

\section{Introduction}

The major aim of this paper is to examine the empirical relations between economic growth and a broad group of political instability factors including corruption, government instability, internal and external conflicts, religious and ethnic tensions, democratic accountability and bureaucracy quality. Moreover, one of the main objectives of our paper is to explore the effects of serious problems such as political instability and corruption on economic growth for Organisation for Economic Co-operation and Development (OECD) countries during the period 1984-2012. Thus, most of the countries in our sample are developed countries of the world.

The main contribution and distinctive characteristic of this article is to focus not only on the relationship between political stability and economic growth, but also on the relations between some specific categories of political instability and economic growth. It is generally accepted that corruption is an element of political instability as well. In this paper, we employ system GMM estimator for linear dynamic panel data models in order to overcome a potential endogeneity problem.

${ }^{a}$ Res. Asst., (Ph.D. Candidate), Gazi University, Faculty of Economics and Administrative Sciences, Ankara, Turkiye, eminahmet@gmail.com

bProf., PhD., Gazi University, Faculty of Economics and Administrative Sciences, Ankara, Turkiye, akcora@gazi.edu.tr 
The relationship between political instability and economic growth has been an issue of concern for long. Political instability is one of the conventional themes of the modern political economy theory. Modern theory of political economy suggests that political stability plays a significant role in economic growth of a country. Thus, an unstable political system could seriously hinder economic growth. Within the theoretical framework of modern political economy, a government is considered to be inefficient if policy objectives vary over a short period of time. Thus, coalition governments are a serious threat and to be more prone to the political stability. Moreover, modern political economy theory emphasizes that political instability also affects the level of economic growth in the country as the rates of economic growth are correlated with persistent policies of government and how government perform these policies (Barro, 2013).

On the other hand, corruption is a widespread phenomenon in several countries around the world, which are regarded by economists as seriously harmful to economic growth (Aisen \& Veiga, 2011). The majority of academic research reveals that corruption impedes economic growth, creates political instability, weakens the state's capacity to tax, undermines spending programs, increases the cost and lowers the quality of public investment (IMF, 2016). Some economists consider that corruption can also have distributional consequences. Corruption increases income inequality and poverty through lower economic growth, biased tax systems favoring the rich, and lower social spending (Gupta, Davoodi \& Alonso-Terme, 2002). However, some researchers suggest that the impact of corruption on economic growth is related with factors such as the country's legal and institutional framework, quality of governance and political regime. Thus, in some highly regulated countries, corruption can compensate for red tape and institutional weaknesses and overcome the government failure in the economy (Campos, Dimova \& Saleh, 2010). Since there is a large consensus that corruption hinders economic growth and increases socio-economic inequalities, international organizations such as the World Bank and OECD emphasize that corruption is among the greatest obstacles to economic and social development (OECD, 2013).

The remaining part of this paper is organized as follows. Section 2 presents a brief literature review. Section 3 provides information about the data, empirical model, and empirical methodology. Section 4 contains empirical results. Section 5 includes a summary and concluding remarks.

\section{Brief Literature Review}

Alesina, Ozler, Roubini, \& Swagel (1992) define political instability narrowly as the tendency of the change in cabinet either by constitutional or unconstitutional means. One of the most important theoretical arguments behind the idea that political instability is a serious obstacle for economic growth is that the uncertainty associated with an unstable political environment may have a negative impact on investment decisions and therefore on the rate of economic growth. Political instability raises uncertainty and risk-averse economic agents may hold back their economic initiatives or may exit the economy, by investing abroad (Alesina et al. 1992: 4). Furthermore, foreign investors prefer to invest in countries with less policy uncertainty and less risk about property rights.

On the other hand, it is argued that an unstable political environment may shorten policy authorities' horizons leading to sub-optimal short-term macroeconomic policies (Aisen \& Veiga, 2011: 3). Political instability may also cause "a more frequent switch of policies, creating volatility and thus, negatively affecting macroeconomic performance" (Aisen \& Vega 2011: 3). Some new political economy models suggest that political instability creates economic inefficiencies. The main idea behind these models is that if a government is uncertain about its survival, it concentrates on suboptimal economic policies in order to worsen the economic environment inherited by its successor (Alesina et al., 1992: 4). On the other hand, a related line of research emphasizes rent-seeking activities to explain the negative relationship between political instability and economic growth (Angelopoulos \& Economides; 2008). Angelopoulos \& Economides (2008: 1375 ) predict that uncertainty about remaining in power leads to increased fiscal expenditures, which in turn distorts incentives by direct individuals away from productive work to rent-seeking activities; the distorted incentives hinder economic growth. Moreover, weak governments are likely to be more sensitive to the demands of pressure groups and therefore rent-seeking activities may have a more direct influence on the decisions of policy-makers. However, an alternative view on this issue is that economic agents may consider 
frequent government changes favorably if the current party in power is incompetent and/or corrupt and the voters view its potential successors as an improvement (Alesina et al., 1992). Analyzing political instabilityeconomic growth nexus in dictatorships, Overland, Simons, \& Michael Spaga (2005) argue that dictators with better survival chances tend to support especially rapid economic development to further increase their longevity in power.

There is an ample amount of empirical literature documenting that political instability affects the economic growth negatively in several countries across time. In their classical paper, Alesina et al. (1992) show that economic growth is lower in countries with a high propensity of government collapse in a panel of 113 countries from the period 1950-1982. Recent papers by Aisen \& Veiga (2011) and Jong-a-Pin (2009) provide evidence showing that there exists a negative relationship between political instability and economic growth. It should be noted that the empirical findings of Jong-a-Pin (2009) are relatively weak and that only the instability of the political regime has a robust and significant negative impact on economic growth. On the other hand, Campos \& Nugent (2002) found no statistically significant long-run relationship between political instability and growth in a sample of 98 developing countries. Employing panel data set covering 19 developing countries for the period 1986-2003, Gür \& Akbulut (2012) find that political instability has a positive and statistically significant effect on economic growth in developing countries. They also present evidence that the estimated country specific effects on economic growth are positive for most of the Asian countries and negative for the Latin American countries. Using Johansen's cointegration analysis, Arslan (2011) provide evidence that there is a long-run relationship between gross domestic product (GDP) and political instability in Turkey for the period 1987-2007.

This paper also aims to investigate empirical relationship between corruption and economic growth by employing the data for OECD countries in the period 1984-2012. Corruption may not influence economic growth (and the level of output) directly, but operates through various channels (OECD, 2013). Corruption may discourage private investment by reducing its profitability or by raising political instability (Alesina et al., 1992). Similarly, corruption tends to lower FDI flows by diminishing its profitability (Javorcik \& Wei, 2009).

Since corruption leads to a decrease in tax revenues, it constrains the ability of governments to provide sufficient level of public services for private sector development. Corruption may divert resources from human capital formation (health and education) and more productive investments to less productive activities, lowering the growth potential of countries (OECD, 2013). Furthermore, Emerson (2006) provides evidence that corruption negatively affects effective competition, identified as a significant determinant of productivity and innovation. By imposing various restrictions on competition to maintain the privileges of established firms or by weakening anti-trust regulations, corruption can undermine effective competition and thus technological progress in many cases (OECD, 2010).

However, some authors argue that it possible for corruption to be beneficial for economic growth (Huntington, 2006; Méon \& Laurent Weill, 2010). Proponents of this view suggest that when a government created widespread and inefficient regulations, then corruption may improve the efficiency of the system and thus contribute to economic growth by overcoming these regulations (Ahmad, Ullah, \& Arfeen, 2012). On the other hand, the so-called East Asian paradox challenges the prevailing argument and empirical evidence that corruption deters investment and reduces the rate of economic growth. Various authors have attempted to explain the high corruption but rapid economic growth puzzle in a number of fairly successful East Asian economies (Larsson, 2006; Ugur \& Dasgupta,2011).

While the majority of empirical literature in the field has consistently provided evidence that corruption negatively affects economic growth, the empirical evidence for beneficial effects of corruption on economic growth is rather limited. Employing cross-section-analysis, Pellegrini \& Gerlagh (2004) find that corruption negatively affects economic growth. Using meta-regression techniques, Campos et al. (2010) conclude that the cross-country macro-econometric evidence provides much greater support for the negative relationship between corruption and economic growth than that for the greasing hypothesis. Applying meta-analysis to evaluate a total of 115 empirical studies, Ugur \& Dasgupta (2011) find that corruption adversely affects economic growth in low income countries as well as in higher income countries. 
Employing Panel Bounds Test Analysis (PARDL), Erkal, Akıncı \& Yılmaz (2014) provide evidence that there is co-integration relationship between corruption and economic growth for OECD and EU countries for the period of 1995-2012. Their empirical findings also indicate that the impact of corruption on economic growth is negative and statistically significant in the long run.

One of the aims of this article is to estimate the empirical relationship between (internal and external) conflict and economic growth. Internal and external conflicts can seriously disrupt growth by destroying physical and human capital. Political conflicts lead to a significant increase in the defense expenditures which constrains spending on human capital (education and health). In addition, increased defense expenditures can crowd out domestic investments which can augment the growth potential of the economy (Gaibulloev \& Sandler, 2009). Furthermore, nearby conflicts can hinder growth by damaging supply lines, bringing about refugee inflows, provoking border clashes, and enhancing defense spending (Gaibulloev \& Sandler, 2009). On the other hand, some authors argue that governments of politically unstable or violent countries are more inclined to rent-seeking, and thus pursue suboptimal taxation policies (Persson \& Tabellini, 2000). Consequently, these types of countries will confront higher levels of debt burden and government spending. Conflict which encourages rent-seeking weakens property rights and the rule of law, implying a poor economic performance for the economy. Similarly, uncertainty about property rights and political instability created by conflict can distort investment and saving incentives (Polachek \& Sevastianova, 2010: 7).

Our article also explores the impact of ethnic and religious tensions on economic growth. The literature reveals that conflict caused by ethnic polarization can negatively influence investment and encourage rent-seeking behavior that increases government spending (Tavares \& Wacziarg, 2001). One strand of the literature suggests that ethnic diversity (or the lack of social cohesion) can destabilize social institutions which in turn may retard economic development (Keefer \& Knack, 2002). Gören (2014) finds that a high level of ethnic diversity implies a lower level of economic growth. However, most of empirical studies show that religious polarization has no impact on economic development.

In this article we also attempt to test the relationship between bureaucracy quality and economic growth. Acemoğlu, Johnson, \& Robinson (2004) argue that differences in institutions fundamentally explain the differences in economic development. Relying on the ideas of new institutional economics, a growing literature emphasizes that institutional quality and good governance matters to economic growth (Kaufmann, Kraay, \& Zoido-Lobaton 1999).

As regards the relationship between democracy and economic growth, the general conclusion of the econometric evidence is that the net impact of democracy on GDP growth is negative or null (Gerring, Bond, Barndt, \& Moreno, 2005). A large theoretical literature stresses negative effects of democracy on economic growth. Alesina \& Rodrik (1994) emphasize the negative impact of democratic redistribution, while Olson (1982) argues that interest group politics in democracy can cause economic stagnation. According to alternative view, democracy can also have positive effects on economic growth by limiting the power of kleptocratic dictators, lessening social conflict or hindering monopolistic gains of politically powerful groups (Acemoglu, Naidu, Restrepo, \& Robinson, 2014).

\section{Data, Empirical Model, and Empirical Methodology}

In this paper we employ annual data of 29 OECD countries for the period 1984-2012. Data used in this paper are obtained from various sources. Regarding the data set for political instability and corruption, they are obtained from Political Risk Services-International Country Risk Guide (PRS-ICRG). The OECD countries in the sample are Australia, Austria, Belgium, Canada, Denmark, Finland, Iceland, Ireland, Japan, Luxemburg, Netherlands, New Zealand, Norway, Sweden, Switzerland, United Kingdom, United States, Chile, France, Greece, Hungary, Italy, Poland, Portugal, Spain, Mexico, Israel, South Korea, and Turkey. The political risk index is based on 100 points and political stability ratings range from a high of 100 (highest political stability) to a low of 0 (lowest political stability). Although corruption measure of PRS group takes financial corruption into account, it is more concerned with actual or potential corruption in the form of excessive patronage, nepotism, job reservations, 'favor-for-favors', secret party funding, and suspiciously close ties 
between politics and business. On the other hand, according to PRS group, the most common form of corruption met directly by business is financial corruption in the form of demands for special payments and bribes connected with import and export licenses, exchange controls, tax assessments, police protection, or loans. The value of corruption index ranges from 0 to 6 , with 0 showing the highest level and 6 indicating the lowest level. In a similar fashion to Kutan, Douglas \& Judge (2009), we reversed the scale of corruption index so that high levels of this index would represent high corruption. We also reversed the scale of internal and external conflict, ethnic and religious tensions, democratic accountability, and bureaucracy quality.

The components of political stability (POL) presented in PRS Group data are government stability (GSTA), internal conflict (INT), external conflict (EXT), corruption (COR), ethnic and religious tensions (ET/RE), democratic accountability (DEM) and bureaucracy quality (BUR). In this paper, the dependent variable is the real GDP growth rate (GRO). Our empirical model includes a set of control variables that affect economic growth. The set of independent variables includes investment (percent of GDP) (INV), human capital proxied by secondary school enrollment rate (HC), inflation rate (INF), trade openness (OPEN), unemployment rate (UN), and population growth rate (POP). The data set regarding independent variables are sourced from International Financial Statistics (IFS).

Investment (or capital accumulation) is one of the most important determinants of economic growth and a positive coefficient is expected. Inflation rate is included in the model as an explanatory variable in order to account for the effects of macroeconomic stability on economic growth. A negative coefficient is expected for inflation as high inflation negatively affects long run economic growth. Openness to trade is added to the model as a proxy reflecting the effect of international factors on economic activity. Since the standard trade theory assumes that international trade foster economic development, a positive coefficient for trade openness is expected. Finally, the empirical model includes population growth rate as an independent variable as an input (or factor) to production. Since modern standard growth theory predicts that greater population growth ceteris paribus leads to lower real GDP per capita growth, a negative coefficient is expected for population growth rate. As endogenous growth theory suggests that human capital fosters economic growth, we expect that the coefficient of human capital is positive.

We use panel data analysis to investigate the effects of political instability and corruption on economic growth for a panel of OECD countries. Panel data analysis is conducted through the system-GMM estimation. Some authors emphasized the potential problem of endogeneity resulting from the fact that causality in the relationship between economic growth and independent variables such as political instability and corruption can run in both directions (Alesina et al., 1992). To deal with this, we apply the GMM estimator which overcomes the problem of endogeneity. Furthermore, the system-GMM estimator developed by Arellano \& Bover (1995) and Blundell \& Bond (1998) deals with the problems associated with the differenceGMM estimator, increasing efficiency.

This paper employs the GMM estimators developed for dynamic models of panel data that were introduced by Arellano and Bover (1995), and Blundell and Bond (1998). Consider the following empirical model for economic growth:

$$
\mathrm{y}_{\mathrm{it}}-\mathrm{y}_{\mathrm{i}, \mathrm{t}-1}=\phi \mathrm{y}_{\mathrm{i}, \mathrm{t}-1}+\beta^{\prime} \mathrm{X}_{\mathrm{it}}+\gamma \mathrm{PI}_{\mathrm{i}, \mathrm{t}}+\eta_{\mathrm{i}}+v_{\mathrm{t}}+\varepsilon_{\mathrm{it}}
$$

where $y_{i t}$ is the natural logarithm of the GDP per capita growth of country $i, X_{i t}$ represents the set of control variables that affect economic growth in natural logarithm (i.e., economic determinants of economic growth), $\mathrm{Pl}_{i, t}$ stands for the components of political stability; $\phi, \gamma$, and $\beta^{\prime}$ are the parameters and vectors of parameters to be estimated; $\eta_{i}$, and $v_{t}$, are country-specific and periodic specific effects respectively, and $\varepsilon_{i t}$ is the error term. Considering $\alpha=1+\phi$, equation (1) can written as follows:

$$
\mathrm{y}_{\mathrm{it}}=\alpha \mathrm{y}_{\mathrm{i}, \mathrm{t}-1}+\beta^{\prime} \mathrm{X}_{\mathrm{it}}+\gamma \mathrm{PI}_{\mathrm{i}, \mathrm{t}}+\eta_{\mathrm{i}}+v_{\mathrm{t}}+\varepsilon_{\mathrm{it}}
$$


The estimation of this dynamic model by using OLS gives rise to biased estimates, a problem called "dynamic panel bias". The reason for this econometric problem is that $y_{i, t-1}$ would be correlated with the error term $\left(\varepsilon_{i t}\right)$. We can remove the country-specific effect $\left(\eta_{i}\right)$ and thus eliminate a potential source of bias by first-differencing equation (2):

$$
\Delta \mathrm{y}_{\mathrm{it}}=\alpha \Delta \mathrm{y}_{\mathrm{i}, \mathrm{t}-1}+\beta^{\prime} \Delta \mathrm{X}_{\mathrm{it}}+\gamma \Delta \mathrm{PI}_{\mathrm{i}, \mathrm{t}}+\Delta \mathrm{v}_{\mathrm{t}}+\Delta \varepsilon
$$

Since components of political stability are likely to be correlated with each other, we estimated the following models separately.

$$
\begin{aligned}
& \Delta \mathrm{y}_{\mathrm{it}}=\alpha_{1} \Delta \mathrm{y}_{\mathrm{i}, \mathrm{t}-1}+\beta_{1}^{\prime} \Delta \mathrm{X}_{\mathrm{it}}+\gamma_{1} \Delta \mathrm{POL}_{\mathrm{i}, \mathrm{t}}+\Delta \mathrm{v}_{1 \mathrm{t}}+\Delta \varepsilon_{\mathrm{it}} \\
& \Delta \mathrm{y}_{\mathrm{it}}=\alpha_{2} \Delta \mathrm{y}_{\mathrm{i}, \mathrm{t}-1}+\beta_{2}^{\prime} \Delta \mathrm{X}_{\mathrm{it}}+\gamma_{2} \Delta \mathrm{COR}_{\mathrm{i}, \mathrm{t}}+\Delta \mathrm{v}_{2 \mathrm{t}}+\Delta \varepsilon \\
& \Delta \mathrm{y}_{\mathrm{it}}=\alpha_{3} \Delta \mathrm{y}_{\mathrm{i}, \mathrm{t}-1}+\beta_{3}^{\prime} \Delta \mathrm{X}_{\mathrm{it}}+\gamma_{3} \Delta \mathrm{GSTA}_{\mathrm{i}, \mathrm{t}}+\Delta \mathrm{v}_{3 \mathrm{t}}+\Delta \varepsilon_{3 \mathrm{it}} \\
& \Delta \mathrm{y}_{\mathrm{it}}=\alpha_{4} \Delta \mathrm{y}_{\mathrm{i}, \mathrm{t}-1}+\beta_{4}^{\prime} \Delta \mathrm{X}_{\mathrm{it}}+\gamma_{4} \Delta \mathrm{ET} / \mathrm{RE}_{\mathrm{i}, \mathrm{t}}+\Delta v_{4 \mathrm{t}}+\Delta \varepsilon_{4 \mathrm{it}} \\
& \Delta \mathrm{y}_{\mathrm{it}}=\alpha_{5} \Delta \mathrm{y}_{\mathrm{i}, \mathrm{t}-1}+\beta_{5}^{\prime} \Delta \mathrm{X}_{\mathrm{it}}+\gamma_{5} \Delta \mathrm{DEM}_{\mathrm{i}, \mathrm{t}}+\Delta \mathrm{v}_{5 \mathrm{t}}+\Delta \varepsilon_{5 \mathrm{it}} \\
& \Delta \mathrm{y}_{\mathrm{it}}=\alpha_{6} \Delta \mathrm{y}_{\mathrm{i}, \mathrm{t}-1}+\beta_{6}^{\prime} \Delta \mathrm{X}_{\mathrm{it}}+\gamma_{6} \Delta \mathrm{BUR}_{\mathrm{i}, \mathrm{t}}+\Delta \mathrm{v}_{6 \mathrm{t}}+\Delta_{6} \varepsilon_{\mathrm{it}} \\
& \Delta \mathrm{y}_{\mathrm{it}}=\alpha_{7} \Delta \mathrm{y}_{\mathrm{i}, \mathrm{t}-1}+\beta_{7}^{\prime} \Delta \mathrm{X}_{\mathrm{it}}+\gamma_{7} \mathrm{INT}_{\mathrm{i}, \mathrm{t}}+\Delta \mathrm{v}_{7 \mathrm{t}}+\Delta \varepsilon_{7 \mathrm{it}} \\
& \Delta \mathrm{y}_{\mathrm{it}}=\alpha_{8} \Delta \mathrm{y}_{\mathrm{i}, \mathrm{t}-1}+\beta_{8}^{\prime} \Delta \mathrm{X}_{\mathrm{it}}+\gamma_{8} \Delta \mathrm{EXT}_{\mathrm{i}, \mathrm{t}}+\Delta v_{8 \mathrm{t}}+\Delta \varepsilon_{8 \mathrm{it}}
\end{aligned}
$$

However, the use of GMM estimator is required to correct the following problems: (i) the potential endogeneity of the independent variables, and (ii) new error term is correlated with the lagged dependent variable. The difference-GMM estimator developed by Arellano and Bond (1991) for linear dynamic panel data models solves this problem by instrumenting the differenced predetermined and endogenous variables with their available lags in levels.

A major problem with this difference-GMM estimator, as Blundell and Bond (1998) show, is that lagged levels of the explanatory variables are weak instruments for the regression equation in differences. To decrease the potential biases and imprecision resulting from this difference estimator, Arellano and Bover (1995) and Blundell and Bond (1998) provide a new estimator (i.e. system-GMM estimator) that combines in a system the regression in differences with the original equation in levels.

\section{Empirical Results}

Before proceeding to system-GMM estimation of the model, we attempted to conduct the tests of panel unit roots on the variables. Ignoring cross-sectional dependence in panel data leads to serious size distortions and power loss. In that case, standard first generation unit root tests cannot be employed. The second generation of unit root tests such as CADF and CIPS are proposed to deal with the cross-sectional dependence. Thus, testing for cross-sectional dependence is important in fitting panel-data models. When $T$ (the panel's time dimension) $>\mathrm{N}$ (the cross-sectional dimension), the use of Lagrange multiplier (LM) test, developed by Breusch and Pagan (1980), is appropriate. On the other hand, when T $<N$, the LM test statistic owns no desirable statistical properties in that it exhibits substantial size distortions. A statistical procedure designed to test for cross-sectional dependence in this type of panels $(T<N)$ is Pesaran's (2004) cross- 
sectional dependence $(C D)$ test. When $T=N$, it is appropriate to employ Pesaran (2004) CDLM2 to test crosssectional dependence in data. ${ }^{1}$

Null and alternative hypotheses for cross sectional dependence testing are as follows:

$\mathrm{H}_{0}$ : No cross sectional dependence

$\mathrm{H}_{1}$ : cross sectional dependence

The results of CDLM tests for cross-sectional dependence are presented in Table 1. According to CDLM2 test results in Table 1, $p$-values are statistically significant for all the variables. Since $T=N(=29)$ in our paper, it is appropriate to focus especially on CDLM2 test results. On the other hand, the results of CDLM and CDLM1 tests generally confirm those of CDLM2 test with a few exceptions (i.e., the absence of cross section dependence is rejected in most of the cases). Thus, empirical results reveal that the hypothesis of crosssectional dependence cannot be rejected by the data.

Table 1. Cross Section Dependence Test Results of the Variables

\begin{tabular}{|c|c|c|c|}
\hline Variables/Tests & $\begin{array}{l}\text { CDLM1 (Breusch \& } \\
\text { Pagan, 1980) }\end{array}$ & $\begin{array}{c}\text { CDLM2 (Pesaran, 2004, } \\
\text { CDLM) }\end{array}$ & $\begin{array}{c}\text { CDLM (Pesaran, 2004, } \\
\text { CD) }\end{array}$ \\
\hline GRO & $719.111(0.000)$ & $10.988(0.000)$ & $-0.873(0.191)$ \\
\hline $\mathrm{HC}$ & $714.142(0.000)$ & $10.814(0.000)$ & $-1.443(0.074)$ \\
\hline INF & $877.724(0.000)$ & $16.554(0.000)$ & $8.852(0.000)$ \\
\hline OPEN & $816.424(0.000)$ & $14.403(0.000)$ & $2.729(0.003)$ \\
\hline POP & $706.158(0.000)$ & $10.533(0.000)$ & $-1.376(0.084)$ \\
\hline INV & $1399.984(0.000)$ & $34.882(0.000)$ & $17.175(0.000)$ \\
\hline $\mathrm{POL}$ & $601.392(0.000)$ & $6.857(0.000)$ & $-1.406(0.000)$ \\
\hline COR & $593.709(0.000)$ & $6.587(0.000)$ & $-3.653(0.000)$ \\
\hline GSTA & $490.517(0.003)$ & $2.966(0.002)$ & $-3.267(0.001)$ \\
\hline $\mathrm{ET} / \mathrm{RE}$ & $535.370(0.000)$ & $4.540(0.000)$ & $-3.548(0.000)$ \\
\hline DEM & $651.097(0.000)$ & $7.326(0.000)$ & $-3.051(0.001)$ \\
\hline BUR & $460.241(0.032)$ & $1.903(0.028)$ & $-3.575(0.000)$ \\
\hline INT & $590.477(0.000)$ & $6.474(0.000)$ & $-3.476(0.000)$ \\
\hline EXT & $552.410(0.000)$ & $5.138(0.000)$ & $-2.464(0.007)$ \\
\hline \multicolumn{4}{|c|}{$\begin{array}{l}\text { Notes: The p-values are presented in parentheses. } \\
\text { GRO = real GDP Growth rate; POL = Political stability; HC = Human capital; INF = Inflation rate; } \\
\text { OPEN = Trade openness; POP = Population growth rate; INV = investment (percent of GDP), COR = corruption, GSTA } \\
\text { = Government stability; ET/RE = Ethnic and religious conflicts; DEM = Democratic Accountability; BUR = Bureaucracy } \\
\text { quality; INT = Internal conflict, EXT = External conflict. }\end{array}$} \\
\hline
\end{tabular}

The CADF and CIPS tests can be used in order to analyze the unit root characteristics of the series in the presence of cross section dependence. Pesaran (2007) suggests an alternative unit root test (CADF) in which the standard ADF regressions are augmented with the cross-section averages of lagged levels and firstdifferences of the individual series. In this procedure, standard panel unit root tests can be based on the simple averages of the individual cross sectionally augmented ADF statistics (denoted by CADF), or suitable transformations of the associated rejection probabilities. He also considers a cross-sectional augmented IPS (CIPS) test, which is a simple average of the individual CADF-tests. CADF tests apply unit root test for every individual country that forms the panel whereas the CIPS test applies the unit root test for the entire panel combining the countries. The CADF and CIPS test results for the series are presented at Tables $2 \mathrm{a}-2 \mathrm{~b}$. Since all the Panel CIPS statistics are statistically significant (with the exception of HC (human capital proxied by secondary school enrollment rate), we can conclude that the series in our panel data contain no unit root except for HC variable. 
Political Instability, Corruption, and Economic Growth: Evidence from a Panel of OECD Countries

Table 2a. Panel Unit Root Test Statistics I (CADF and CIPS Tests)

\begin{tabular}{|c|c|c|c|c|c|c|c|}
\hline & GRO & HC & INF & OPEN & POP & INV & POL \\
\hline Australia & $-4.881^{a}$ & -2.864 & -1.362 & -2.165 & -2.782 & -3.093 & $-4.180^{b}$ \\
\hline Austria & -2.464 & -2.566 & -2.374 & -2.039 & -2.598 & -2.956 & -2.726 \\
\hline Belgium & $-3.545^{c}$ & -2.429 & -3.101 & -1.246 & -1.363 & -2.635 & -2.934 \\
\hline Canada & $-4.007^{b}$ & -3.196 & $-5.076^{a}$ & -1.157 & -1.661 & -1.485 & -2.614 \\
\hline Chile & $-3.538^{c}$ & -4.116 & -2.723 & -1.367 & -2.224 & -2.438 & -3.161 \\
\hline Denmark & -3.198 & -2.681 & -2.302 & -2.090 & -2.128 & -2.512 & $-3.672^{c}$ \\
\hline Finland & $-3.686^{c}$ & -2.262 & -2.888 & -2.388 & -0.532 & -2.294 & -2.488 \\
\hline France & -2.941 & -1.003 & -2.956 & -2.751 & -1.559 & -2.411 & -2.675 \\
\hline Greece & -2.317 & -0.073 & $-3.537^{c}$ & $-3.932^{b}$ & -1.844 & -2.744 & -0.822 \\
\hline Hungary & -2.336 & -1.917 & -1.240 & -2.305 & -3.025 & -2.017 & $-5.113^{a}$ \\
\hline Iceland & $-3.692^{c}$ & -1.201 & -1.492 & -0.083 & -5.481 & -2.098 & -3.122 \\
\hline Ireland & -1.602 & -0.319 & -2.532 & -1.999 & -1.427 & -1.678 & $-4.487^{b}$ \\
\hline Israel & $-3.574^{c}$ & -2.674 & $-42.294^{a}$ & -2.331 & -2.401 & -2.076 & -3.703 \\
\hline Italy & $-4.641^{b}$ & -1.781 & $-5.200^{\mathrm{a}}$ & -3.267 & -2.872 & -2.531 & -2.239 \\
\hline Japan & -1.155 & -2.186 & -3.134 & -2.069 & -3.015 & -2.435 & -1.813 \\
\hline Korea, Rep. & $-3.996^{b}$ & -3.358 & -2.608 & -1.449 & -1.951 & -2.419 & $-4.086^{b}$ \\
\hline Luxembourg & -2.199 & -2.419 & $-4.833^{a}$ & -2.754 & -1.486 & -2.881 & -0.990 \\
\hline Mexico & -3.171 & -2.993 & 0.023 & -2.469 & $-4.147^{b}$ & -1.686 & -2.770 \\
\hline Netherlands & -1.689 & -2.406 & -1.843 & 0.394 & $-4.276^{b}$ & -3.008 & -3.246 \\
\hline New Zealand & -2.356 & -3.440 & -2.898 & 0.582 & -2.738 & -3.017 & -2.304 \\
\hline Norway & -3.229 & -2.841 & $-4.331^{b}$ & -5.015 & -1.224 & -2.018 & -1.606 \\
\hline Poland & -2.800 & -2.203 & $-8.096^{a}$ & -1.699 & -1.019 & -2.684 & $-4.474^{b}$ \\
\hline Portugal & $-3.501^{c}$ & -1.860 & $-3.922^{b}$ & -1.762 & -0.224 & -1.983 & -2.241 \\
\hline Spain & $-3.973^{b}$ & -2.440 & -2.066 & -1.310 & -2.482 & -0.964 & -3.665 \\
\hline Sweden & $-3.616^{c}$ & -1.924 & $-6.251^{a}$ & -2.571 & -2.347 & -2.460 & -1.120 \\
\hline Switzerland & -2.890 & -0.569 & $-3.705^{c}$ & 0.531 & -1.896 & -3.207 & -3.268 \\
\hline Turkey & $-3.934^{b}$ & -3.291 & -1.648 & -3.702 & -1.576 & -2.385 & $-3.558^{c}$ \\
\hline United Kingdom & -2.978 & -3.130 & $-4.018^{b}$ & -1.855 & -1.744 & -2.935 & -3.134 \\
\hline United States & -2.608 & -1.778 & $-3.502 c$ & -2.100 & -1.873 & -1.497 & -3.041 \\
\hline $\begin{array}{c}\text { Panel } \\
\text { (CIPS-stat) }\end{array}$ & $-3.114^{a}$ & -2.273 & $-4.535^{a}$ & $-2.940^{a}$ & $-2.590^{c}$ & $-2.664^{b}$ & $-2.936^{a}$ \\
\hline
\end{tabular}

Notes: (1) The letters ${ }^{a},{ }^{b}$, and ${ }^{c}$ indicate the statistical significance at the 1,5 and $10 \%$ levels of significance, respectively; (2) The number of lags was set to 2; (3) Panel unit root test regressions include a constant and trend. 
E. A. Kaplan - A. Akcoraglu

Table 2b. Panel Unit Root Test Statistics II (CADF and CIPS Tests)

\begin{tabular}{|c|c|c|c|c|c|c|c|}
\hline & COR & GSTA & ET / RE & DEM & BUR & INT & EXT \\
\hline Australia & $-3.525^{c}$ & -2.169 & $-3.907^{b}$ & $-3.639^{c}$ & $-3.552^{b}$ & $-4.763^{a}$ & -0.822 \\
\hline Austria & $-3.774^{c}$ & -3.029 & $-3.587^{c}$ & $-4.029^{b}$ & $-4.314^{b}$ & $-4.806^{a}$ & -2.723 \\
\hline Belgium & $-3.506^{c}$ & $-4.752^{a}$ & $-4.054^{b}$ & $-3.766^{c}$ & $-4.771^{a}$ & $-5.823^{a}$ & $-4.005^{b}$ \\
\hline Canada & $-3.547^{c}$ & -2.784 & $-6.439^{a}$ & $-4.207^{b}$ & $-4.735^{a}$ & $-6.699^{a}$ & -1.850 \\
\hline Chile & $-3.592^{c}$ & -2.515 & $-4.38^{b}$ & -2.896 & $-3.697^{c}$ & $-4.335^{b}$ & -3.023 \\
\hline Denmark & $-3.927^{c}$ & $-3.901^{b}$ & $-4.096^{b}$ & -3.410 & $-3.940^{b}$ & $-4.830^{\mathrm{a}}$ & -2.100 \\
\hline Finland & $-3.586^{c}$ & -2.003 & $-3.707^{c}$ & $-3.927^{b}$ & $-4.760^{\mathrm{a}}$ & $-5.155^{a}$ & -3.407 \\
\hline France & $-3.890^{b}$ & $-4.113^{b}$ & $-4.829^{a}$ & $-3.692^{c}$ & $-4.023^{b}$ & $-4.530^{b}$ & -2.465 \\
\hline Greece & $-4.376^{b}$ & $-3.627^{c}$ & $-4.916^{a}$ & $-3.703^{c}$ & $-4.255^{b}$ & $-4.704^{a}$ & -3.430 \\
\hline Hungary & $-3.894^{b}$ & $-5.251^{a}$ & $-4.918^{a}$ & $-5.295^{a}$ & -2.857 & $-5.020^{a}$ & $-4.815^{b}$ \\
\hline Iceland & $-4.771^{a}$ & -2.870 & $-3.948^{b}$ & $-4.114^{b}$ & $-4.156^{b}$ & $-5.549^{a}$ & $-3.556^{\mathrm{a}}$ \\
\hline Ireland & $-4.790^{a}$ & $-3.764^{c}$ & -3.314 & $-3.683^{c}$ & $-4.300^{b}$ & $-4.764^{a}$ & -2.207 \\
\hline Israel & $-4.767^{a}$ & -2.445 & $-3.571^{c}$ & $-3.915^{b}$ & $-4.442^{b}$ & $-3.913^{b}$ & -2.393 \\
\hline Italy & $-5.187^{a}$ & $-3.773^{c}$ & $-4.697^{\mathrm{a}}$ & $-4.429^{b}$ & $-4.112^{b}$ & $-4.327^{b}$ & -3.361 \\
\hline Japan & $-5.480^{a}$ & -2.814 & $-5.224^{a}$ & $-4.716^{a}$ & $-3.535^{c}$ & $-6.228^{a}$ & $-4.713^{a}$ \\
\hline Korea, Rep. & $-4.170^{b}$ & $-5.307^{a}$ & $-4.962^{a}$ & $-5.510^{a}$ & $-3.583^{c}$ & $-4.070^{b}$ & -2.476 \\
\hline Luxembourg & $-4.119^{b}$ & -2.602 & $-5.425^{a}$ & $-4.257^{b}$ & $-4.270^{b}$ & $-4.497^{b}$ & -1.888 \\
\hline Mexico & $-4.080^{b}$ & $-3.661^{c}$ & $-4.457^{b}$ & -3.220 & -3.071 & -3.094 & -2.752 \\
\hline Netherlands & -3.012 & $-5.625^{a}$ & $-4.459^{b}$ & -2.619 & -3.105 & $-4.245^{b}$ & $-3.617^{c}$ \\
\hline New Zealand & -3.141 & -2.991 & $-5.081^{a}$ & $-3.841^{c}$ & $-3.978^{b}$ & $-5.042^{a}$ & -2.539 \\
\hline Norway & $-3.714^{c}$ & $-3.532^{c}$ & $-4.782^{a}$ & $-3.955^{b}$ & $-3.898^{b}$ & $-4.481^{b}$ & $-4.740^{\mathrm{a}}$ \\
\hline Poland & $-4.063^{b}$ & $-3.754^{c}$ & $-5.430^{a}$ & $-3.579^{c}$ & $-3.547^{c}$ & $-4.819^{a}$ & $-4.746^{a}$ \\
\hline Portugal & $-3.581^{c}$ & -3.240 & $-5.128^{a}$ & -3.182 & -3.331 & $-5.695^{a}$ & -2.241 \\
\hline Spain & $-3.710^{c}$ & -2.982 & $-5.433^{a}$ & -2.660 & $-3.964^{b}$ & $-4.493^{b}$ & -3.360 \\
\hline Sweden & $-4.187^{b}$ & -1.572 & $-4.569^{b}$ & -2.945 & -2.693 & $-5.095^{a}$ & $-6.567^{a}$ \\
\hline Switzerland & $-3.720^{c}$ & $-4.751^{a}$ & $-4.011^{b}$ & -2.984 & -3.133 & $-4.384^{a}$ & -3.179 \\
\hline Turkey & -2.829 & $-4.043^{b}$ & $-3.947^{b}$ & $-3.994^{b}$ & $-4.693^{\mathrm{a}}$ & $-4.754^{a}$ & -2.500 \\
\hline United Kingdom & $-3.582^{c}$ & $-4.833^{a}$ & $-5.374^{a}$ & -3.081 & -2.918 & $-6.485^{a}$ & -1.154 \\
\hline United States & -2.992 & $-4.029^{b}$ & $-4.190^{b}$ & -3.122 & $-3.649^{c}$ & $-5.130^{a}$ & -1.521 \\
\hline Panel (CIPS-stat) & $-3.875^{a}$ & $-3.529^{a}$ & $-4.570^{a}$ & $-3.733^{a}$ & $-3.824^{a}$ & $-4.887^{a}$ & $-3.040^{a}$ \\
\hline
\end{tabular}

Note: See Notes to Table 2a.

The main results of the system-GMM estimation of the relationship between economic growth and political stability are presented in Table 3. Since $\Delta y_{i t}\left(=\ln Y_{i t}-\ln Y_{i t-1}\right)$ is mathematically (and approximately) equal to real GDP growth, we employed real GDP growth as dependent variable. We used two period lagged values of independent variables as instruments in the first-difference equations and their once lagged firstdifferences in levels equation in all system-GMM estimations.

It is clear from Table 3 that the coefficient of political stability variable is positive and statistically significant at the 1.5 percent level of significance. Thus, the hypothesis that political stability positively affects economic growth is strongly supported by the system-GMM estimation results for the data of OECD countries. 
Table 3. Political Stability and Economic Growth

\begin{tabular}{|c|c|c|c|c|}
\hline \multicolumn{5}{|l|}{ Dependent Variable: GRO } \\
\hline Variable & Coefficient & Standard Error & T-statistic & Probability \\
\hline GRO(-1) & $0.3014^{\mathrm{a}}$ & 0.0664 & 4.5400 & 0.0000 \\
\hline HC & $-0.0266^{\mathrm{c}}$ & 0.0152 & -1.7500 & 0.0800 \\
\hline INF & -0.0006 & 0.0047 & -0.1200 & 0.9050 \\
\hline OPEN & $-1.3522^{\mathrm{b}}$ & 0.5534 & -2.4400 & 0.0150 \\
\hline POP & $-1.3332^{\mathrm{a}}$ & 0.3139 & -4.2500 & 0.0000 \\
\hline INV & 0.0652 & 0.0472 & 1.3800 & 0.1670 \\
\hline POL & $0.0599^{\mathrm{b}}$ & 0.0245 & 2.4400 & 0.0150 \\
\hline
\end{tabular}

Notes: (1) Arellano and Bover (1995) and Blundell and Bond (1998) two-step system-GMM estimations for dynamic panel data models; (2) Sample period: 1984-2012. Number of countries: 29; (3) All independent variables were treated as endogenous; (4) The letters ${ }^{a},{ }^{b}$, and ${ }^{~}$ indicate the statistical significance at the 1,5 and $10 \%$ levels of significance, respectively.; (4) The standard errors presented are 'robust clustered standard errors'; (5) Number of observations: 812.

Wald-F statistic $=276.99$, Wald Test Probability $=0.00$, Hansen exogeneity test statistic $=26.96($ prob $=1.0)$.

GRO = real GDP Growth rate; POL = Political stability; HC = Human capital; INF = Inflation rate;

OPEN = Trade openness; POP = Population growth rate; INV = investment (percent of GDP).

Table 4. Corruption and Economic Growth

\begin{tabular}{|c|c|c|c|c|}
\hline \multicolumn{5}{|l|}{ Dependent Variable: GRO } \\
\hline Variable & Coefficient & Standard Error & T-statistic & Probability \\
\hline GRO(-1) & $0.3105^{\text {a }}$ & 0.0676 & 4.5900 & 0.0000 \\
\hline HC & 0.0125 & 0.0106 & 1.1700 & 0.2400 \\
\hline INF & 0.0000 & 0.0041 & 0.0100 & 0.9910 \\
\hline OPEN & -0.5371 & 0.5353 & -1.0000 & 0.3160 \\
\hline POP & $-0.9697^{\mathrm{a}}$ & 0.2470 & -3.9300 & 0.0000 \\
\hline INV & $0.0814^{\mathrm{c}}$ & 0.0492 & 1.6600 & 0.0980 \\
\hline COR & $-0.3671^{\mathrm{a}}$ & 0.1279 & -2.8700 & 0.0040 \\
\hline
\end{tabular}

Notes: See notes to Table 3 for information in (1)-(5).

Wald-F statistic $=166.50$, Wald Test Probability $=0.00$, Hansen exogeneity test: test statistic $=26.35($ prob.$=1.0)$.

COR $=$ Corruption. For the definition of other variables, see Table 3.

On the other hand, Table 4 presents the results associated with the empirical relationship between economic growth and corruption. According to the results reported in Table 4, the coefficient of corruption is negative as expected and statistically significant at the 1 percent level. The sign of coefficient associated with corruption variable conforms to the theoretical expectation that corruption has a deleterious effect on economic growth. Thus, system-GMM estimation results presented in Table 4 provide empirically strong support for the hypothesis that corruption negatively affects economic growth for a panel of OECD countries.

This article also investigates the effects of some political instability components on economic growth for a panel of OECD countries. The results of the system-GMM estimation of the relationship between economic growth and political instability components are reported in Table 5. 
Table 5. System-GMM Estimations: Components of Political Instability and Economic Growth

\begin{tabular}{|c|c|c|c|c|c|c|}
\hline \multicolumn{7}{|c|}{ Dependent Variable: GRO } \\
\hline Variables: & (1) & (2) & (3) & (4) & $(5)$ & (6) \\
\hline GRO(-1) & $\begin{array}{c}0.2977^{a} \\
(0.0000)\end{array}$ & $\begin{array}{c}0.3200^{\mathrm{a}} \\
(0.0000)\end{array}$ & $\begin{array}{c}0.3204^{\mathrm{a}} \\
(0.0000)\end{array}$ & $\begin{array}{c}0.3210^{\mathrm{a}} \\
(0.0000)\end{array}$ & $\begin{array}{c}0.3117^{\mathrm{a}} \\
(0.0000)\end{array}$ & $\begin{array}{c}0.3113^{\mathrm{a}} \\
(0.0000)\end{array}$ \\
\hline $\mathrm{HC}$ & $\begin{array}{c}-0.0017 \\
(0.8480) \\
\end{array}$ & $\begin{array}{c}0.0121 \\
(0.2630) \\
\end{array}$ & $\begin{array}{r}0.0067 \\
(0.4820) \\
\end{array}$ & $\begin{array}{c}0.0098 \\
(0.2990) \\
\end{array}$ & $\begin{array}{c}0.0111 \\
(0.3010) \\
\end{array}$ & $\begin{array}{c}0.0103 \\
(0.3320) \\
\end{array}$ \\
\hline INF & $\begin{array}{c}0.0006 \\
(0.8900) \\
\end{array}$ & $\begin{array}{c}0.0024 \\
(0.6300) \\
\end{array}$ & $\begin{array}{l}0.0004 \\
(0.9360) \\
\end{array}$ & $\begin{array}{c}0.0002 \\
(0.9590)\end{array}$ & $\begin{array}{l}0.0033 \\
(0.4100) \\
\end{array}$ & $\begin{array}{c}0.0005 \\
(0.9110)\end{array}$ \\
\hline OPEN & $\begin{array}{c}-1.3221^{b} \\
(0.0460) \\
\end{array}$ & $\begin{array}{l}-0.8197 \\
(0.1400) \\
\end{array}$ & $\begin{array}{c}-0.9800^{c} \\
(0.0820) \\
\end{array}$ & $\begin{array}{l}-0.9485 \\
(0.1370) \\
\end{array}$ & $\begin{array}{l}-0.6353 \\
(0.2460) \\
\end{array}$ & $\begin{array}{l}-0.4060 \\
(0.4270)\end{array}$ \\
\hline POP & $\begin{array}{c}-1.1856^{a} \\
(0.0000) \\
\end{array}$ & $\begin{array}{l}-0.9638^{a} \\
(0.0010) \\
\end{array}$ & $\begin{array}{c}-1.1129^{\mathrm{a}} \\
(0.0000) \\
\end{array}$ & $\begin{array}{c}-1.0869^{a} \\
(0.0000) \\
\end{array}$ & $\begin{array}{l}-0.9654^{\mathrm{a}} \\
(0.0010)\end{array}$ & $\begin{array}{c}-0.9471^{\mathrm{a}} \\
(0.0000)\end{array}$ \\
\hline INV & $\begin{array}{c}0.0745 \\
(0.1230) \\
\end{array}$ & $\begin{array}{r}0.0835^{c} \\
(0.0900) \\
\end{array}$ & $\begin{array}{r}0.0806^{c} \\
(0.1090) \\
\end{array}$ & $\begin{array}{r}0.0827^{c} \\
(0.0910) \\
\end{array}$ & $\begin{array}{c}0.0839^{c} \\
(0.0920) \\
\end{array}$ & $\begin{array}{l}0.0823^{c} \\
(0.0980)\end{array}$ \\
\hline GSTA & $\begin{array}{c}0.2220^{\mathrm{a}} \\
(0.0040)\end{array}$ & & & & & \\
\hline $\mathrm{ET} / \mathrm{RE}$ & & $\begin{array}{l}-0.2249 \\
(0.1710) \\
\end{array}$ & & & & \\
\hline DEM & & & $\begin{array}{c}0.0771 \\
(0.6580) \\
\end{array}$ & & & \\
\hline BUR & & & & $\begin{array}{l}-0.0056 \\
(0.9890) \\
\end{array}$ & & \\
\hline INT & & & & & $\begin{array}{l}-0.3345^{a} \\
(0.0140) \\
\end{array}$ & \\
\hline EXT & & & & & & $\begin{array}{c}-0.3889^{a} \\
(0.0020) \\
\end{array}$ \\
\hline $\begin{array}{l}\text { Notes: See no } \\
\text { Model 1: Wal } \\
=216.4 \text { (prot } \\
0.00 \text { ), Hanse } \\
\text { exogeneity te } \\
=26.35 \text { (prob } \\
\text { GSTA = Gov } \\
\text { Bureaucracy }\end{array}$ & $\begin{array}{l}\text { T Table } 3 \text { for } \\
\text { at. = } 189.65 \\
\text { 00), Hansen } \\
\text { geneity test } \\
\text { t. = } 26.82 \text { ( } p \\
\text { ), Model } 6: \\
\text { ent stability; } \\
\text { y; INT = Inte }\end{array}$ & $\begin{array}{l}\text { ormation in ( } \\
\text { b. = 0.00), Ha } \\
\text { ogeneity test } \\
\text { t. = } 26.51 \text { (p } \\
=1.0), \text { Mode } \\
\text { d-F stat. = } 18 \\
\text { /RE = Ethnic } \\
\text { I conflict, EXT }\end{array}$ & $\begin{array}{l}\text {. P-values a } \\
\text { n exogeneity } \\
\text { t. }=27.23 \text { (p } \\
=1.0 \text { ), Mod } \\
\text { Wald-F stat. } \\
\text { (prob. = } 0.0 \\
\text { religious c } \\
\text { xternal confli }\end{array}$ & $\begin{array}{l}\text { resented in } p \\
\text { stat. = } 27.14 \\
=1.0 \text { ), Mode } \\
\text { Wald-F stat } \\
5.82 \text { (prob. = } \\
\text { ansen exoge } \\
\text { cts; DEM = } \\
\text { or the defini }\end{array}$ & $\begin{array}{l}\text { theses. } \\
\text { b.= 1.0), Mo } \\
\text { Wald-F stat. } \\
02.78 \text {, (prob } \\
\text { ), Hansen ex } \\
\text { test stat. = } \\
\text { ocratic Acco }\end{array}$ & $\begin{array}{l}\text { 2: Wald-F stat } \\
71.42 \text { (prob. } \\
0.00 \text { ), Hanser } \\
\text { neity test stat } \\
2 \text { (prob.= 1.0) } \\
\text { ability; BUR } \\
\text { s, see Table } 1\end{array}$ \\
\hline
\end{tabular}

Although the system-GMM estimation results in Table 5 reveal that the signs of all coefficients associated with political instability components conform to theoretical expectations, some of them are insignificant at the conventional levels. The seventh row of the first column in the Table 5 indicates that government stability, a narrow measure of political stability, has a positive and statistically significant impact on economic growth. The coefficient of government stability variable is statistically significant at the $1 \%$ level. Thus, our empirical results provide strong evidence regarding the negative effect of government instability on the rate of economic growth. The coefficients of variables representing internal and external conflict are negative and statistically significant (at the $1 \%$ level), implying that rising internal and external conflict leads to a decline in the rate of economic growth. According to the classification of PRS group, the subcomponents of internal conflict are: civil war/coup threat, terrorism/political violence, civil disorder. On the other hand, the subcomponents of external conflict include: war, cross-border conflict, and foreign pressures. The results demonstrate that the coefficient of ethnic and religious tensions is negative as expected, but it is statistically insignificant. The results in Table 5 indicate that the coefficient of democratic accountability is positive, but statistically insignificant. Thus, the results of system-GMM estimation provide 
no evidence in favor of the hypothesis that democracy contributes to faster economic growth for a panel of OECD countries. As regards bureaucracy quality, we find that it is statistically insignificant and has a theoretically unexpected negative sign.

Table 6. Fixed-Effects Regression Results: Components of Political Instability and Economic Growth

\begin{tabular}{|c|c|c|c|c|c|c|c|c|}
\hline \multicolumn{9}{|c|}{ Dependent Variable: GRO } \\
\hline Variables & (1) & (2) & (3) & (4) & (5) & (6) & (7) & (8) \\
\hline Cons & $\begin{array}{l}-3.589^{b} \\
(-2.280)\end{array}$ & $\begin{array}{l}2.624^{\mathrm{a}} \\
(2.480) \\
\end{array}$ & $\begin{array}{c}1.272 \\
(1.160) \\
\end{array}$ & $\begin{array}{l}2.954^{\mathrm{a}} \\
(2.740) \\
\end{array}$ & $\begin{array}{c}1.848 \\
(1.580) \\
\end{array}$ & $\begin{array}{l}3.286^{\mathrm{a}} \\
(2.980) \\
\end{array}$ & $\begin{array}{c}3.310^{\mathrm{a}} \\
(3.030) \\
\end{array}$ & $\begin{array}{r}2.962^{\mathrm{a}} \\
(2.790) \\
\end{array}$ \\
\hline SE & $\begin{array}{l}-0.0264^{a} \\
(-2.830)\end{array}$ & $\begin{array}{c}-0.014 \\
(-1.530)\end{array}$ & $\begin{array}{l}-0.023^{a} \\
(-2.440)\end{array}$ & $\begin{array}{l}-0.019^{b} \\
(-1.990)\end{array}$ & $\begin{array}{l}-0.0213^{b} \\
(-2.250)\end{array}$ & $\begin{array}{l}-0.020^{\mathrm{b}} \\
(-2.160)\end{array}$ & $\begin{array}{l}-0.022^{b} \\
(-2.290)\end{array}$ & $\begin{array}{l}-0.019^{b} \\
(-1.980)\end{array}$ \\
\hline INF & $\begin{array}{c}-0.001 \\
(-0.270) \\
\end{array}$ & $\begin{array}{l}-0.007^{b} \\
(-1.920) \\
\end{array}$ & $\begin{array}{l}-0.004 \\
(-1.11) \\
\end{array}$ & $\begin{array}{c}-0.005 \\
(-1.460) \\
\end{array}$ & $\begin{array}{l}-0.0039 \\
(-1.110) \\
\end{array}$ & $\begin{array}{c}-0.004 \\
(1.040) \\
\end{array}$ & $\begin{array}{c}-0.005 \\
(-1.400) \\
\end{array}$ & $\begin{array}{c}-0.005 \\
(-1.410) \\
\end{array}$ \\
\hline OPEN & $\begin{array}{c}-0.763 \\
(-1.370) \\
\end{array}$ & $\begin{array}{c}0.112 \\
(0.190) \\
\end{array}$ & $\begin{array}{l}-0.727 \\
(-1.30) \\
\end{array}$ & $\begin{array}{c}-0.451 \\
(-0.800) \\
\end{array}$ & $\begin{array}{l}-0.6273 \\
(-1.110) \\
\end{array}$ & $\begin{array}{l}-0.519 \\
(0.920) \\
\end{array}$ & $\begin{array}{c}-0.288 \\
(-0.510) \\
\end{array}$ & $\begin{array}{c}-0.207 \\
(-0.360) \\
\end{array}$ \\
\hline POP & $\begin{array}{l}-0.662^{\mathrm{a}} \\
(-2.720)\end{array}$ & $\begin{array}{l}-0.671^{a} \\
(-2.730)\end{array}$ & $\begin{array}{l}-0.565^{b} \\
(-2.310)\end{array}$ & $\begin{array}{l}-0.656^{\mathrm{a}} \\
(-2.650)\end{array}$ & $\begin{array}{l}-0.603^{a} \\
(-2.430)\end{array}$ & $\begin{array}{l}-0.646^{\mathrm{a}} \\
(2.610)\end{array}$ & $\begin{array}{l}-0.675^{a} \\
(-2.730)\end{array}$ & $\begin{array}{l}-0.669^{a} \\
(-2.710)\end{array}$ \\
\hline INV & $\begin{array}{c}0.077^{\mathrm{a}} \\
(4.690)\end{array}$ & $\begin{array}{c}0.090^{\mathrm{a}} \\
(5.480)\end{array}$ & $\begin{array}{r}0.079^{a} \\
(4.800)\end{array}$ & $\begin{array}{c}0.091^{\mathrm{a}} \\
(5.480)\end{array}$ & $\begin{array}{l}0.0877^{\mathrm{a}} \\
(5.260)\end{array}$ & $\begin{array}{c}0.090^{\mathrm{a}} \\
(5.430)\end{array}$ & $\begin{array}{c}0.089^{a} \\
(5.370)\end{array}$ & $\begin{array}{r}0.089^{\mathrm{a}} \\
(-2.480)\end{array}$ \\
\hline $\mathrm{POL}$ & $\begin{array}{c}0.097^{a} \\
(5.430)\end{array}$ & & & & & & & \\
\hline COR & & $\begin{array}{l}-0.408^{a} \\
(-3.160)\end{array}$ & & & & & & \\
\hline GSTA & & & $\begin{array}{c}0.293^{\mathrm{a}} \\
(5.000)\end{array}$ & & & & & \\
\hline $\mathrm{ET} / \mathrm{RE}$ & & & & $\begin{array}{c}-0.066 \\
(-0.820)\end{array}$ & & & & \\
\hline DEM & & & & & $\begin{array}{c}0.260^{\mathrm{b}} \\
(1.940)\end{array}$ & & & \\
\hline BUR & & & & & & $\begin{array}{l}-0.418^{c} \\
(1.630)\end{array}$ & & \\
\hline INT & & & & & & & $\begin{array}{l}-0.159^{b} \\
(-2.010)\end{array}$ & \\
\hline EXT & & & & & & & & $\begin{array}{l}-0.206^{a} \\
(-2.480) \\
\end{array}$ \\
\hline $\begin{array}{l}\text { Number } \\
\text { of obs. }\end{array}$ & 841 & 841 & 841 & 841 & 841 & 841 & 841 & 841 \\
\hline $\begin{array}{c}\text { No. of } \\
\text { countries }\end{array}$ & 29 & 29 & 29 & 29 & 29 & 29 & 29 & 29 \\
\hline R-sq. & 0.0897 & 0.0680 & 0.0848 & 0.0572 & 0.0608 & 0.0595 & 0.0611 & 0.0636 \\
\hline sigma_u & 1.682 & 1.265 & 1.195 & 1.169 & 1.272 & 1.274 & 1.189 & 1.233 \\
\hline sigma_e & 2.557 & 2.588 & 2.564 & 2.602 & 2.597 & 2.599 & 2.596 & 2.593 \\
\hline rho & 0.302 & 0.192 & 0.178 & 0.168 & 0.193 & 0.193 & 0.173 & 0.184 \\
\hline F test & $\begin{array}{c}5.35 \\
(0.00) \\
\end{array}$ & $\begin{array}{c}4.63 \\
(0.00) \\
\end{array}$ & $\begin{array}{c}4.81 \\
(0.00) \\
\end{array}$ & $\begin{array}{c}4.25 \\
(0.00) \\
\end{array}$ & $\begin{array}{c}3.94 \\
(0.00) \\
\end{array}$ & $\begin{array}{c}3.90 \\
(0.00) \\
\end{array}$ & $\begin{array}{c}4.38 \\
(0.00) \\
\end{array}$ & $\begin{array}{c}4.41 \\
(0.00) \\
\end{array}$ \\
\hline
\end{tabular}

Note: T-statistics are given in parentheses. The letters ${ }^{a},{ }^{b}$, and ${ }^{c}$ indicate the statistical significance at the 1,5 and $10 \%$ levels of significance, respectively. 
On the other hand, we present fixed-effects regression results in Table 6 in order to check for the robustness of the panel system-GMM estimations. The fixed-effects regression results in Table 6 are generally consistent with the estimation results of the system-GMM. However, the fixed-effects regression results show that the coefficient associated with democracy is positive and statistically significant, whereas it is insignificant according to the results of system-GMM estimation. Moreover, the coefficient of bureaucracy quality is statistically significant at the $10 \%$ level in fixed-effects estimation, but it has a negative sign in contrast with the theoretical expectations.

With regard to control variables that affect economic growth, most of the results conform to the predictions of economic theory with some exceptions. The coefficient of population is negative as expected and statistically significant in all cases. According to our results, investment has a positive impact on economic growth and statistically significant in most of the cases. While the coefficient of inflation rate variable is positive and statistically insignificant in all model specifications in the system-GMM results, it is negative and statistically significant in a single case in the fixed-effects regression results. On the other hand, the coefficient of human capital variable is statistically insignificant in most of the model specifications in the system-GMM estimation results. On the contrary to the predictions of conventional trade theory, the coefficient of trade openness variable is negative, but insignificant, in most of the cases.

\section{Conclusion}

The fundamental contribution of this paper is to investigate the links between a variety of political instability factors and economic growth by applying advanced panel data estimation techniques. Furthermore, this paper re-examines the impact of political instability and corruption on economic growth by using a panel of OECD countries. Employing a sample comprised of relatively advanced countries of the world (with a few exceptions), we find that political instability are negatively associated with economic growth. Moreover, this article provides strong evidence in favor of the hypothesis that corruption adversely affects rates of economic growth in OECD countries. Thus, these results confirm the conclusions of most of the previous empirical research cited in section 2 of this paper.

This article presents strong evidence in favor of the view that internal and external conflicts are obstacles for rapid economic growth, confirming the findings of previous empirical studies mentioned in section 2. Although panel fixed-effects results portrayed in this paper provide empirical support in favor of the view that democracy is beneficial for economic growth at the 5 percent of statistical significance, this estimation result is not robust as the system-GMM indicates a statistically insignificant relationship. As regards ethnic and religious tensions and bureaucracy quality, the results of system-GMM estimation reveal that they do not have a statistically significant impact on economic growth rates of OECD countries.

The overall empirical results presented in this paper suggest that political instability has a significant negative effect on economic growth and governments should take corrective measures to bring political stability. Moreover, strong and systematic implementation of the various elements of the anticorruption agenda is necessary to address the impact of corruption on long run economic growth. Dealing with bribery and building transparent and accountable public institutions will help enhance investment, competition and government efficiency. On the other hand, an anti-corruption campaign should mainly concentrate on the reforms of civil service, judiciary system, tax and customs departments. Moreover, recruiting and promoting civil servants on a merit basis, and paying them a salary competitive to private sector alternatives enhances the efficiency and ethical values of the government bureaucracy.

On the other hand, diminishing internal and external conflicts is a prerequisite to political stability, which, in turn, is the prerequisite for carrying out pro-growth policies. The presence of conflict limits the policies governments can exert to bolster growth. The standard approach to tackle internal conflict is to use the police forces to establish law and order in the country. As an alternative, the government authorities may choose to implement egalitarian economic policies in order to deal with the distributional or political factors that led to the conflict. Furthermore, initiatives for peace agreements and regional cooperation efforts can help tackle the political conflicts. 


\section{End Notes}

1. Furthermore, Pesaran et al. (2008) propose a bias-adjusted version of Breusch \& Pagan (1980) LM test statistic of error cross-section independence, in the presence of stricly exogenous regressors and normal errors.

\section{References}

Acemoglu, D., Johnson, S., \& Robinson, J.A. (2004). Institutions as the fundamental cause of long-run growth. NBER Working Paper 10481.

Acemoglu, D., Naidu, S., Restrepo, P., \& Robinson, J.A. (2014). Democracy does cause growth. NBER Working Paper 20004.

Ahmad, E., Ullah, M.A., \& Arfeen, M.I. (2012). Does corruption affect economic growth? Latin American Journal of Economics, 49(2), 277-305.

Alesina, A., \& Rodrik, D. (1994). Distributive politics and economic growth. Quarterly Journal of Economics, 109(2), 465490.

Alesina, A., Özler, Ş., Roubini, N., \& Swagel, P. (1992). Political instability and economic growth. NBER Working Paper 4173.

Aisen, A., \& Veiga, F.J. (2011). How does political instability affect economic growth? IMF Working Paper WP/11/12.

Angelopoulos, K., \& Economides, G. (2008). Fiscal policy, rent seeking, and growth under electoral uncertainty: Theory and evidence from the OECD. Canadian Journal of Economics, 41(4), 1375-1405.

Arellano, M., \& Bover O. (1995). Another look at the instrumental variable estimation of error-components models. Journal of Econometrics, 68, 29-52.

Arslan, Ü. (2011). Siyasi istikrarsizlik ve ekonomik performans: Türkiye örneği, Ege Akademik Bakış / Ege Academic Review, 11(1), $73-80$.

Blundell, R., \& Bond, S. (1998). Initial conditions and moment restrictions in dynamic panel-data models. Journal of Econometrics, 87, 115-143.

Breusch, T.S., \& Pagan, A.R. (1980). The lagrange multiplier test and its applications to model specification tests in econometrics. Review of Economic Studies, 47(1), 239-53.

Campos, N.F., \& Nugent, J. (2002). Who is afraid of political instability? Journal of Development Economics, 67, 157-172.

Campos, N.F., Dimova, R., \& Saleh, A. (2010). Whither corruption?: A quantitative survey of the literature on corruption and growth. IZA Discussion Paper 5334.

Emerson, P.M. (2006). Corruption, competition and democracy. Journal of Development Economics, 81, 193 - 212.

Erkal, G., Merter, A., \& Yılmaz, Ö. (2014). Yolsuzluk ve iktisadi büyüme ilişkisi: OECD ve AB ülkeleri üzerine panel sınır testi analizi. Sayıştay Dergisi, 76, 5-22.

Gaibulloev, K., \& Sandler, T. (2009). The impact of terrorism and conflicts on growth in Asia. Economics \& Politics, 21(3), 359-383.

Gerring, J., Bond, P., Barndt, W., \& Moreno, C. (2005). Democracy and growth: A historical perspective. World Politics, 57(3), 323-64.

Gören, E. (2014). How ethnic diversity affects economic growth. World Development, 59, 275-297.

Gupta, S., Davoodi, H., \& Alonso-Terme, R. (2002). Does corruption affect income inequality and poverty? Economics of Governance, 3(1), 23-45.

Gür, T.H., \& Akbulut, H. (2012). Gelişmekte olan ülkelerde politik istikrarın ekonomik büyüme üzerine etkisi. Sosyoekonomi, 17(17), 281-300.

Huntington, S.P. (2006). Political Order in Changing Societies. New Haven: Yale University Press, (Orig. Pub. 1968).

IMF (2016). Corruption: costs and mitigating strategies. IMF Staff Discussion Note, SDN/16/05.

Javorcik, B.S., \& Wei, S.-J. (2009). Corruption and cross-border Investment in emerging markets: Firm-level evidence. Journal of International Money and Finance, 28(4), 605-624.

Jong-a-Pin, R. (2009). On the measurement of political Instability and its impact on economic growth. European Journal of Political Economy, 25, 15-29. 
Kaufmann, D., Kraay, A., \& Zoido-Lobaton, P. (1999). Governance matters. World Bank Policy Research Working Paper 2196.

Keefer, P., \& Knack, S. (2002). Polarization, politics and property rights: Links between inequality and growth. Public Choice, 111, 127-54.

Kutan, A.M., Douglas, T.J., \& Judge, W.Q. (2009). Does corruption hurt economic development?: Evidence from middle eastern and north african and latin american countries. Serdar Sayan (Ed.), Economic Performance in the Middle East and North Africa: Institutions, Corruption and Reform (pp. 25-37). London: Rutledge.

Larsson, T. (2006). Reform, corruption, and growth: Why corruption is more devastating in Russia and China. Communist and Post-Communist Studies, 39, 265-281.

Méon, P.G., \& Weill, L. (2010). Is corruption an efficient grease? World Development, 38(3), 244-259.

OECD. (2010). Competition assesment toolkit http://www.oecd.org/competition/assessment-toolkit.htm (accessed June 2016).

OECD. (2013). Corruption and economic growth. Paper presented to the G20 Leaders at the St. Petersburg Summit in September 2013.

Olson, M. (1982). The rise and decline of nations. New Haven and London: Yale University Press.

Overland, J., Simons, K., \& Spaga M. (2005). Political instability and growth in dictatorships. Public Choice, 125(3-4), 445470.

Pellegrini, L., \& Gerlach, R. (2004). Corruption's effect on growth and its transmission channels. Kyklos, 57(3), 429-456.

Persson, T., \& Tabellini, G. (2000). Political Economics- Explaining Economic Policy. Cambridge, Massachusetts: MIT Press.

Pesaran, M.H. (2004). General diagnostic tests for cross section dependence in panels. Cambridge Working Papers in Economics, No.435, University of Cambridge.

Peseran, M.H. (2007). A simple panel unitroot test in the presence of cross-section dependence. Journal of Applied Econometrics, 22, 265-312.

Pesaran, M.H., Ullah, A. \& Yamagata, T. (2008). A bias-adjusted LM test of error cross-section independence. Econometrics Journal, 11(1), 105-127.

Polachek, S.W., \& Sevastianova, D. (2010). Does conflict disrupt growth? Evidence of the relationship between political Instability and national economic performance. IZA Discussion Paper Series, DP 4762.

Tavares, J., \& Wacziarg, T. (2001). How democracy affects growth. European Economic Review, 45, $1341-1378$.

Ugur, M., \& Dasgupta, N. (2011). Evidence on the economic growth impacts of corruption in low income countries and beyond: A systematic review. EPPI-Centre Report 1914 (University of London). 
This Page Intentionally Left Blank 